\title{
Efficacy of Selected Plant Extracts against Pyricularia grisea, Causal Agent of Rice Blast Disease
}

\author{
Judith Hubert1,2*, Robert B. Mabagala1, Delphina P. Mamiro ${ }^{1}$ \\ ${ }^{1}$ Department of Crop Science and Production, Sokoine University of Agriculture, Morogoro, Tanzania \\ ${ }^{2}$ Africa Rice Center, Dar es Salaam, Tanzania \\ Email: ${ }^{*}$ hubertjudith@yahoo.com
}

Received 10 February 2015; accepted 11 March 2015; published 12 March 2015

Copyright @ 2015 by authors and Scientific Research Publishing Inc.

This work is licensed under the Creative Commons Attribution International License (CC BY).

http://creativecommons.org/licenses/by/4.0/

\section{c) (7) Open Access}

\begin{abstract}
Rice blast disease, caused by a seed-borne fungus Pyricularia grisea, is an important and serious disease of rice (Oryza sativa L.) worldwide. The disease has been reported to cause yield losses of up to $40 \%$ in Tanzania. Studies were conducted to determine the effect of aqueous extracts of Aloe vera, Allium sativum, Annona muricata, Azadirachta indica, Bidens pilosa, Camellia sinensis, Chrysanthemum coccineum, processed Coffee arabica, Datura stramonium, Nicotiana tabacum and Zingiber officinalis for control of rice blast disease (Pyricularia grisea) in-vitro and in-vivo. The results indicate that processed $C$. arabica at $10 \%$ and $25 \%(\mathrm{v} / \mathrm{v})$ had the highest $(81.12 \%)$ and $(89.40 \%)$ inhibitory effect, respectively, against $P$. grisea. Aqueous extract from $N$. tabacum at $10 \%$ concentration ranked third $(80.35 \%)$ in inhibiting $P$. grisea. These were followed by extracts from $25 \% A$. vera $(\mathbf{7 9 . 4 5 \% )}$ ) and $25 \%$ C. coccineum flower $(78.83 \%)$. The results also indicate that, extracts from A. indica, A. vera, A. sativum, C. arabica, D. stramonium, C. sinensis, Z. officinalis and $N$. tabacum did not have any phytotoxic effect on seed germination, shoot height, root length, dry weight, seedling growth and seedling vigour index. These plant extracts can thus be used for rice seed treatment to manage rice blast disease.
\end{abstract}

\section{Keywords}

Plant Extracts, Pyricularia grisea, Rice

\section{Introduction}

Rice blast disease, caused by a seed-borne fungus Pyricularia grisea, is an important and serious disease of rice

*Corresponding author.

How to cite this paper: Hubert, J., Mabagala, R.B. and Mamiro, D.P. (2015) Efficacy of Selected Plant Extracts against Pyricularia grisea, Causal Agent of Rice Blast Disease. American Journal of Plant Sciences, 6, 602-611.

http://dx.doi.org/10.4236/ajps.2015.65065 
(Oryza sativa L.) worldwide [1]-[3]. The disease has been reported to cause yield losses of up to $40 \%$ in Tanzania [4]. Rice blast disease is one of the major factors causing losses in quality and quantity of rice [5]. Smallscale farmers in Tanzania keep their harvested rice seeds for sowing in the following season. This practice facilitates multiplication of $P$. grisea within the seed and becomes a source of inoculum for new infection [6].

Management of rice blast is difficult because the pathogen is seed-borne. Management approaches have mainly focused on the use of synthetic chemicals and resistant rice varieties [7]. In Tanzania, rice blast management has been limited to foliar spray with fungicides such as Dithane M-45 (80\% of Mancozeb) and Benlate (50\% of Benomyl) [8]. However, their efficacy can be limited by the rapid development of resistance of the pathogen to these chemicals. Chemicals applied as either seed dressing or spray such as Abendazim, Benomyl, Benomyl + Copper sulphate, probenazole, thiabendazole and pyroquilon fungicides have been used in different rice growing countries to manage rice blast disease [9]. However, such chemicals are expensive, not easily available to small-scale farmers and have detrimental effects on the environment, farmer and consumer health, beneficial predators and parasitoids [10]. These fungicides have also been reported to affect useful organisms used in biological control programs [11] [12]. Amadioha [13] reported water and ethanol leaf extracts and oil extract of seeds of Azadirachta indica to be effective in reducing radial growth of $P$. grisea in-vitro and development and spread of blast disease in rice plants. Therefore, natural plant products (botanicals) are becoming a new source of agricultural chemicals [13] to manage plant diseases.

Plant extracts have been known for their medicinal and antimicrobial properties since ancient times [14] [15]. They offer a greater scope than synthetic chemicals as they are relatively safe, easily biodegradable and ecofriendly [2] [11] [16] [17]. Gurjar et al. [17] reported that plant extracts from Azadirachta indica, A. Juss., Allium sativum, Linn., Eucalyptus globulus, Labill., Curcuma longa, Linn., Nicotiana tabacum, Linn and Zingibar officinale, Rose inhibited growth of pathogens such as Phytopthora infestans, Alternaria alternate, Rhizoctonia solani and Curvularia lunata. Natural chemicals from plants are cheap, readily available and cost-effective in developing countries where synthetic fungicides are scarce and expensive for resource-poor farmers [7].

The main focus of the present study was to evaluate efficacy of plant extracts against $P$. grisea in-vitro and in-vivo and phytotoxicity of plant extracts on rice plant development.

\section{Materials and Methods}

\subsection{Seed Samples}

Rice (Oryza sativa) seed samples of nineteen different rice genotypes were used in this study. Among the collected seed samples, ten (Mbawambili, Masantula, Bishori, Domo la fisi, Kisegese, Mzambia, Kaniki, Karamata, Dongo la Songea and Usiniguse) were local accessions, while Supa, Kihogo red and Afaa Mwanza were varieties commonly grown in many areas. Released varieties were IR 64, Kalalu, Mwangaza, TXD 85, TXD 88 and Saro 5. The collected seed samples were transported to the African Seed Health Centre (AfSHC) laboratory at Sokoine University of Agriculture and stored at $4^{\circ} \mathrm{C}$ for further testing.

\subsection{Isolation and Preparation of Pyricularia grisea Inoculum}

Cultures of $P$. grisea used in this study were isolated from infected rice seeds collected from Mvomero, Kilosa and Kilombero districts, Morogoro region, Tanzania. The germinating spores and mycelia were picked with a slightly bent inoculating needle and transferred to the Petri dishes containing Potato Dextrose Agar (31.2 g Potato Dextrose Agar powder and $800 \mathrm{ml}$ of distilled water) at 4 equidistant points [18]. The Petri dishes were sealed with masking tape and incubated at alternating temperatures of about $28^{\circ} \mathrm{C}-32^{\circ} \mathrm{C}$ for five days in alternating cycles of $12 \mathrm{~h}$ light and darkness to induce growth of $P$. grisea and were kept upside down. The pure cultures of the isolates were grown on V8 agar (3 g Calcium Carbonate, $200 \mathrm{ml} \mathrm{V-8} \mathrm{juice} \mathrm{and} 20 \mathrm{~g}$ agar in 800 $\mathrm{ml}$ of distilled water) for 14 days to induce sporulation. The V-8 agar was used for producing $P$. grisea conidia. The petri dishes containing $P$. grisea inoculum were stored in the refrigerator at $5{ }^{\circ} \mathrm{C}$ [19] for further use.

\subsection{Sources of Plant Extracts}

Plants used as sources of extracts in this study are listed in Table 1. Fresh leaves (about $3 \mathrm{~kg}$ ) of each plant species were harvested using a sterilized pair of scissors and put in perforated sacs and labeled properly for location, date and name of plant species. The samples were sent to the African Seed Health Centre (AfSHC) screen house 
Table 1. Plants used as sources of antifungal extracts in the study.

\begin{tabular}{ccc}
\hline Common name & Scientific name & Area (region) collected \\
Neem & Azadirachta indica & Morogoro \\
Aloe & Aloe vera & Morogoro \\
Garlic & Allium sativum & Iringa \\
Black jack & Bidens pilosa & Morogoro \\
Soursop & Annona muricata & Morogoro \\
Coffee & Coffee arabica & Morogoro \\
Thorn apple & Datura stramonium & Mbeya \\
Pyrethrum & Chrysanthemum coccineum & Iringa \\
Tobacco & Nicotiana tabacum & Iringa \\
Ginger & Zingiber officinalis & Iringa \\
Tea & Camellia sinensis & Mbeya \\
\hline
\end{tabular}

for further processing.

\subsection{Preparation of Plant Extracts}

Leaves of plants presented in Table 1 were washed with running tape water to remove soil materials, and rinsed with Sterile Distilled Water (SDW) three times. The leaf samples were then cut into small pieces and placed on benches in the screen house at $25^{\circ} \mathrm{C}-28^{\circ} \mathrm{C}$ to dry for 3 to 4 weeks. The dried leaves of each plant species were made into powder separately using a sterilized mortar and pestle and then sieved with one millimeter sieve. The powder of each plant species was packed in water proof plastic bags and labeled appropriately as described by Akinbode and Ikotun [20] and stored at $4{ }^{\circ} \mathrm{C}$ until used [21]. Crude plant extracts were obtained by infusing $50 \mathrm{~g}$ of each plant material in $100 \mathrm{ml} \mathrm{SDW}$ to give $50 \% \mathrm{w} / \mathrm{v}$ in a $500 \mathrm{ml}$ conical flask and the mixture was incubated at $25^{\circ} \mathrm{C}-28^{\circ} \mathrm{C}$ for 20 hours [22] [23]. The infusion was filtered separately through sterile double-layered cheese cloth into a sterile $400 \mathrm{ml}$ beaker and the resulting stock solution was collected and stored at $25^{\circ} \mathrm{C}-28^{\circ} \mathrm{C}$ until used [24].

\subsection{Amendment of PDA with Plant Extracts}

Four different concentrations (1\%,5\%, 10\% and 25\%) of each plant extract were prepared and added directly to the sterile PDA through sterile micro-filters in the laminar flow chamber. The stock solutions were removed and measured by a $10 \mathrm{ml}$ syringe without a needle. To prepare these concentrations, two, 10, 20 and $50 \mathrm{ml}$ of the stock solutions were mixed in $198 \mathrm{ml}, 190 \mathrm{ml}, 180 \mathrm{ml}$ and $150 \mathrm{ml}$, respectively, of autoclaved PDA as described by Kamalakannan and Shanmugam [25]. The PDA medium with plant extracts (PDAPE) were poured into Petri dishes $(20 \mathrm{ml})$ and allowed to solidify and then stored at $5^{\circ} \mathrm{C}$ until used.

\subsection{In-Vitro Assay of Plant Extracts against Pyricularia grisea}

The fungitoxic effect of different plant extracts in-vitro were studied by inoculating PDA with 14-day-old pure cultures of $P$. grisea [19]. Small mycelia segments $(5 \mathrm{~mm})$ were made using a sterile $5 \mathrm{~mm}$ diameter cork borer. Each mycelial segment was then transferred singly onto the centre of each PDAPE Petri dishes at 1\%, 5\%, 10\% and $25 \%$ concentrations (v/v). The PDA Petri dishes without plant extracts were used as negative control and PDA mixed with Apron Star ${ }^{\circledR} 42$ WS contained 20\% Thiamethoxam, 20\% Metalaxyl-M and 2\% Difenoconazole, trade names Cruiser and Actara were included as positive controls. The experiments were laid out in a split plot in a randomized complete block design with rice blast as main plot and plant extracts as a subplots with 50 treatments (12 plant extracts with 4 different concentrations and 2 controls: Apron Star ${ }^{\circledR} 42$ WS and distilled water). The inoculated Petri dishes were sealed with masking tape and incubated at $28^{\circ} \mathrm{C}-32^{\circ} \mathrm{C}$ for five days in alternating cycles of 12 hours light and darkness to induce growth of $P$. grisea. Radial growth of $P$. grisea was then recorded after every three days for up to 21 days after inoculation by measuring mycelial growth diameters along two diagonal lines previously drawn on the reverse side of each Petri dish to serve as a reference, using a $30 \mathrm{~cm}$ plastic ruler to determine the effectiveness of plant extracts. Calculation of percent inhibition of fungal 
growth was estimated based on Ogbeborand Adekunle [26] methods as follows: Percentage mycelial inhibition $=100$ (Mycelial growth diameter in control-Mycelial growth diameter in treatment)/Mycelial growth diameter in control. The treatments that showed high percentage control in in-vitro by reducing $P$. grisea growth were selected and the experiments were repeated twice.

\subsection{In-Vivo Assay of Plant Extracts against P. grisea}

\subsubsection{Seed Inoculation with $P$. grisea}

Four hundred seeds of a susceptible rice variety Supa were spray-inoculated with $1 \times 10^{5}$ spores $/ \mathrm{ml}$ of $P$. grisea strain following procedures of Namai and Ehara [27]. Inoculated seeds were dried in the laminar flow chamber on three layers of blotter papers in Petri dishes for $2 \mathrm{~h}$. Seeds were stored at $4^{\circ} \mathrm{C}$ until used.

\subsubsection{Treatment of Inoculated Seeds with Plant Extracts}

The most promising concentrations of plant extracts in in-vitro were used in in-vivo. Twenty five per cent suspensions of extracts of Azadirachta indica, Aloe vera, Allium sativum, Coffee arabica, Camellia sinensis, Datura stramonium, Nicotiana tabacum and Zingiber officinalis were prepared by soaking $15 \mathrm{~g}$ of plant parts (ground leaves and seeds) in $60 \mathrm{ml}$ of SDW. Ten per cent suspension of Nicotiana tabacum extracts was also prepared by soaking $6 \mathrm{~g}$ of leaves in $60 \mathrm{ml}$ of SDW for $20 \mathrm{~h}$ [22]. The extracts were filtered using double-layered cheesecloth and the volume was adjusted to $60 \mathrm{ml}$ with SDW and put in $80 \mathrm{ml}$ scotch bottle with cover. The extracts were then kept at $4^{\circ} \mathrm{C}$ until used.

Rice seeds (pre-inoculated with $P$. grisea) were soaked in suspensions of each pre-determined concentrations of plant extract overnight and then dried on sterile blotter papers for $2 \mathrm{~h}$ on the laminar flow chamber. The seeds were placed in a beaker and $40 \mathrm{ml}$ of each plant extract suspension was added. The seeds were gently stirred by a stirring glass rod to ensure that they were completely immersed and evenly distributed. Beakers containing inoculated seed were covered by aluminum foil to reduce external contaminations and placed at the constant temperature of $25^{\circ} \mathrm{C}$ for $20 \mathrm{~h}$.

Two hundred seeds in 4 replicates (50 seeds per replicate) were tested per plant extract. Treated seeds were planted in pots (25 seeds/pot) containing a mixture of sandy-loam soil:farmyard manures (3:1) and kept under screen house conditions $\left(25^{\circ} \mathrm{C}-30^{\circ} \mathrm{C}\right.$ and $\left.85 \%-95 \% \mathrm{RH}\right)$. The efficacy of plant extract treatments in the control of $P$. grisea incidence in rice seedling was obtained by assessing rice seedlings for disease incidence and severity at 15, 20, 25, 30 and 35 days after sowing [28]. Scores for disease severity were done using the international scale (0 - 9 scale) developed by International Rice Research Institute [4]. In addition, the height of seedlings and leaves were evaluated. The weight of seedlings was evaluated 35 days after sowing. The height of the seedlings was determined using a ruler by measuring aerial part of the seedling from the soil surface to the terminal node of the developing leaf. To determine the fresh weight, rice seedlings were carefully cut at the bottom of the stem using a pair of scissors and the seedlings were placed on a weighing balance.

\subsection{Evaluation of Phytotoxicity of Plant Extracts on Rice Seed Germination, Seedling Growth and Vigour}

The effect of plant extracts on seed germination, seedling growth and vigour tests were carried out to determine whether the plant extracts were harmful. Seed germination tests were carried out using Between Paper method [29]. Four hundred seeds from three different rice varieties (Mwangaza, Saro-5 and Supa) were transferred separately to a beaker containing $40 \mathrm{ml}$ suspensions of extracts from $25 \%$ (v/v) of Azadirachta indica, Aloe vera, Allium sativum, Camellia sinensis, Datura stramonium, Nicotiana tabacum, Zingiber officinalis and $10 \%$ Coffee arabica based on their best performance in the in-vitro and in-vivo assays. Seeds were soaked in the plant extract(s) for $24 \mathrm{~h}$ at $25^{\circ} \mathrm{C}$ and dried on sterile blotter papers for $2 \mathrm{~h}$ on the laminar flow chamber [30]. Rice seeds soaked in SDW and Apron Star $^{\circledR} 42$ WS treatments were included in the experiments as negative and positive controls, respectively.

The effect of plant extracts on seed germination was evaluated by counting the number of normal seedlings, abnormal seedlings and dead seeds as recommended byInternational Seed Testing Association [29] Seedling Evaluation Handbook. Four hundred seeds in four replicates of hundred seeds of each sample were placed between two layers of moist germination papers. The germination papers were then folded along one edge and rolled up carefully ensuring that no excess pressure was placed on the seeds. The rolled germination papers were 
tied with rubber bands at both ends and put into the transparent plastic bags tied at the top. To prevent the bending, paper towels were transferred in a basket with a flat base $(\mathrm{W} \times \mathrm{L} \times \mathrm{H}=9.8 \mathrm{~cm} \times 9.8 \mathrm{~cm} \times 9.8 \mathrm{~cm})$ and then placed in the incubation room at $25^{\circ} \mathrm{C}-28^{\circ} \mathrm{C}$ for 14 days. The shoot length, root length and dry weight of seedlings were measured and recorded 14 days after sowing in order to evaluate the effect of the extracts on seedling growth and vigour [29]. The seedling shoots were cut, kept separately in paper bags and dried in an electric oven maintained at $80^{\circ} \mathrm{C}$ temperature for $24 \mathrm{~h}$ as described by Chhetri [31]. After drying, the shoot dry weights were recorded by an electric balance. In order to obtain the seedling growth rate (gram per plant) the total weight of dry seedlings per roll of germination paper towels was divided by total number of normal seedlings as described by International Seed Testing Association [29] Seedling Evaluation Handbook.

\subsection{Data Analysis}

All data collected were analyzed based on the split plot arrangement in a CRD analysis of variance (ANOVA) model using GenStat statistical software. The data for disease incidence and severity of seed-borne fungal pathogens including $P$. grisea and the level of seed infection per sample and percentage germination test (abnormal seedlings, dead seeds and hard seeds) were subjected to square root transformation to normalize the data before analysis. A constant value (0.5) was added to each observation before taking square root [13]. Means were separated by Duncan's multiple range test (DMRT) at $\mathrm{P}=0.05$.

\section{Results and Discussion}

Results indicate that the concentrations of the tested plant extracts against $P$. grisea had a positive effect in inhibiting mycelia growth. The results of $P$. grisea growth on PDA amended with plant extracts showed that $A$. indica, A. vera, A. sativum, C. arabica, C. coccineum, D. stramonium, C. sinensis, Z. officinalis and $N$. tabacum had antifungal properties against $P$. grisea at high (25\%) but not at low (1\%) concentrations in in-vitro (Table 2). For each plant extract studied, the inhibitory effect on $P$. grisea at $10 \%$ and $25 \%$ concentrations was significantly higher $(\mathrm{P}<0.001)$ than $1 \%$ and $5 \%$ concentrations, except for B. pilosa and A. muricata where the difference between extract concentrations was not significant $(\mathrm{P}<0.05)$. The extracts from $C$. arabica at $25 \%$ with $89.40 \%$ gave the highest radial growth inhibition of $P$. grisea, while the lowest $(0.8 \%)$ radial growth inhibition was recorded on PDA amended with plant extracts from A. muricata at 5\% (Table 2). It was generally observed that $A$. indica had fungicidal properties at all tested concentrations unlike other plant extracts tests. Our results are in close agreement to those reported by Amadioha [13] and Kamalakannan et al. [32] who observed that neem extract at different concentrations reduced the radial growth of $P$. grisea on PDA medium and incidences and severity of rice blast in-vivo. The effects of plant extracts increased with increasing concentration except extract from $N$. tabacum, which showed maximum mycelial inhibition at $10 \%$ concentration and thereafter, stimulated mycelial growth at a concentration of 25\% (Table 2). Taiga and Friday [33] reported that N. tabacum, A. vera and $A$. indica extracts contain alkaloids and flavonoids; while $N$. tabacum extract that was observed to be more fungi toxic at $10 \%$ concentration contained an additional component (tannins), which has been reported to be absent in both A. vera and A. indica extracts.

Seed extracts of processed C. arabica at $10 \%$ and $25 \%$ had the best inhibitory effect (81.12 and $89.40 \%$ ), respectively, against $P$. grisea (Figure 1). They were followed by extracts from $10 \% N$. tabacum (80.35\%), 25\% A. vera (79.45\%), 25\% C. coccineum flower (78.83\%), 5\% N. tabacum (78.33\%), 25\% C. arabica $(77.52 \%), 10 \%$ A. vera (76.15\%), 25\% Z. officinalis (75.60\%), 10\% A. indica (74.90\%), 10\% C. coccineum $(71.18 \%), 5 \%$ A. indica (69.38\%), 25\% A. sativum (68.75\%), 10\% A. sativum (67.25\%), 5\% C. coccineum flower (61.73\%) and 25\% N. tabacum (61.15\%) (Table 2). Similarly, Hajano et al. [34] evaluated garlic, neem and calatropis plant extracts and found that only garlic extract at higher dose successively reduced the infection caused by Magnaporthe oryzae on rice. It was also observed that neem extract at high dose $4 \mathrm{ml} / 15 \mathrm{ml}$ medium moderately inhibited the radial growth of $M$. oryzae.

Such results indicate that these plant extracts may have fungicidal properties that can be used as seed treatments for controlling P. grisea, the causal agent of rice blast. The antifungal properties of $Z$. officinalis on Aspergilus flavus, Aspergilus niger, Fusarium solani and Fusarium oxysporum on post-harvest yam (Dioscorea alata, Poir) has been reported by Yeni [35]. Other researchers also reported that Z. officinalis has been used for relief from arthritis, rheumatism, coughs, fever and infectious diseases [36]. The highest mycelial growth of $P$. grisea was favored by $5 \%$ B. pilosa $(-10.92 \%)$ and $1 \%(-1.57 \%)$ (Table 2). The effect of N. tabacum on P. gri- 
Table 2. Percentage inhibition of radial growth of Pyricularia grisea on Potato Dextrose Agar mixed with plant extracts at various (v/v) concentrations.

\begin{tabular}{|c|c|c|c|c|}
\hline \multirow[t]{2}{*}{ Name of treatment } & \multicolumn{4}{|c|}{ Plant extracts (\% inhibition of mycelial growth) } \\
\hline & $1 \%$ & $5 \%$ & $10 \%$ & $25 \%$ \\
\hline \multicolumn{5}{|l|}{ Control } \\
\hline SDW & $-3.23 \mathrm{~h}$ & $-3.72 \mathrm{j}$ & $-3.47 \mathrm{j}$ & $-3.38 \mathrm{j}$ \\
\hline Apron Star ${ }^{\circledR} 42$ WS & $35.80 \mathrm{ab}$ & $50.5 \mathrm{~d}$ & $82.1 \mathrm{a}$ & 89.8 a \\
\hline \multicolumn{5}{|l|}{ Extracts source } \\
\hline Zingiber officinalis & $22.68 \mathrm{~d}$ & $28.90 \mathrm{f}$ & $45.95 \mathrm{e}$ & $75.60 \mathrm{c}$ \\
\hline Azadirachta indica & $37.23 \mathrm{ab}$ & $69.38 \mathrm{~b}$ & $74.90 \mathrm{~b}$ & 77.52 bc \\
\hline Coffee arabica & $34.08 \mathrm{~b}$ & $50.58 \mathrm{~d}$ & 81.12 a & $89.40 \mathrm{a}$ \\
\hline Camellia sinensis & $7.75 \mathrm{f}$ & $16.23 \mathrm{~h}$ & $35.10 \mathrm{~g}$ & $52.40 \mathrm{f}$ \\
\hline Nicotiana tabacum & 26.82 c & 78.33 a & 80.35 a & $61.15 \mathrm{e}$ \\
\hline Aloe vera & 16.38 e & $27.73 \mathrm{f}$ & $76.15 \mathrm{~b}$ & $79.45 b$ \\
\hline Datura stramonium & $4.43 \mathrm{fg}$ & $23.15 \mathrm{~g}$ & $39.25 \mathrm{f}$ & $49.10 \mathrm{~g}$ \\
\hline Allium sativum & $17.35 \mathrm{e}$ & $36.25 \mathrm{e}$ & $67.25 \mathrm{~d}$ & $68.75 \mathrm{~d}$ \\
\hline Annona muricata & $0.80 \mathrm{gh}$ & $1.73 \mathrm{i}$ & $2.10 \mathrm{i}$ & $3.42 \mathrm{i}$ \\
\hline Chrysanthemum coccineum (leaf) & 19.05 de & $20.98 \mathrm{~g}$ & $23.25 \mathrm{~h}$ & $26.00 \mathrm{~h}$ \\
\hline Bidens pilosa & $-1.57 \mathrm{~h}$ & $-10.92 \mathrm{k}$ & $-7.38 \mathrm{k}$ & $-5.43 \mathrm{j}$ \\
\hline Chrysanthemum coccineum (flower) & 39.70 a & $61.73 \mathrm{c}$ & $71.18 \mathrm{c}$ & $78.83 \mathrm{~b}$ \\
\hline Mean & 18.38 & 32.20 & 47.70 & 53.04 \\
\hline $\mathrm{LSD}_{0.05}$ & 3.97 & 3.57 & 3.13 & 2.35 \\
\hline F test & & & & \\
\hline Variance & 7.72 & 6.28 & 4.83 & 2.72 \\
\hline
\end{tabular}

*Values are means of four replicates in two separate experiments. Numbers followed by the same letters in a column are not significantly different at $\mathrm{P}=0.05$, using Duncan's Multiple Range Test; ${ }^{* * *}=$ highly significantly different $(\mathrm{P}<0.001)$.
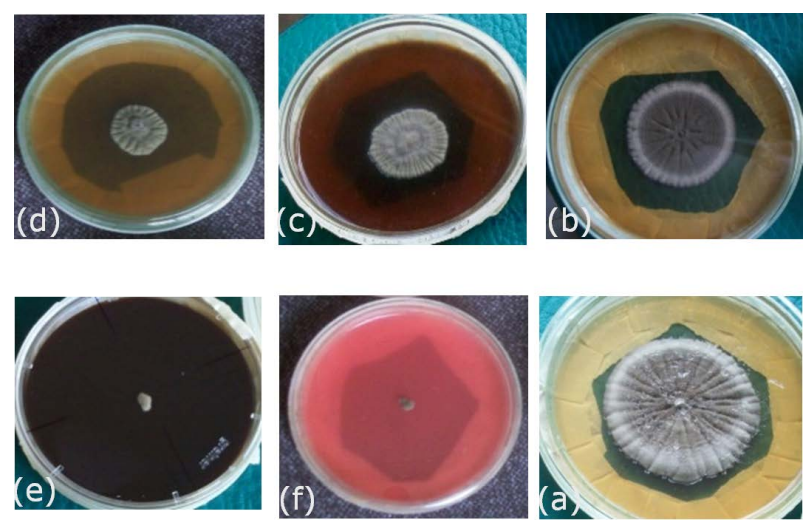

Figure 1. Growth of endophytic fungal mycelia on PDA amended with processed Coffee arabica: (a) = PDA amended with sterile distilled water (negative control), (b) = PDA amended with $1 \%$, (c) = PDA amended with $5 \%$, (d) = PDA amended with $10 \%$, (e) = PDA amended with $25 \%$ and (f) = PDA amended with Apron star Apron Star 42 WS (positive control) 21 days after incubation.

sea at $1 \%, 5 \%$ and $10 \%$ levels showed subsequent increase in percentage of fungal growth inhibition and decrease at $25 \%$ (Table 2). These results suggest that the optimal concentration of $N$. tabacum leaf extracts was around $10 \%$.

The shoot length of rice seedlings of cultivar Mwangaza were significantly different $(\mathrm{P}<0.05)$ when treated with plant extracts, Apron Star ${ }^{\circledR} 42$ WS and SDW. Seedlings of rice cultivar Mwangaza treated with Apron Star $^{\circledR} 42$ WS had the shortest shoot length $(10.71 \mathrm{~cm})$ compared with those treated with plant extracts and SDW (Table 3). There were no significant differences $(\mathrm{P}<0.05)$ between the root length, dry weight, seedling growth rate and vigour index of cultivar Mwangaza for all treatments (Table 3). These results generally indicated that, 
Table 3. Effect of treatment with plant extracts on growth and development of rice plants in in-vitro using the between paper method.

\begin{tabular}{|c|c|c|c|c|c|c|c|}
\hline \multirow[b]{2}{*}{ Rice varieties } & \multirow[b]{2}{*}{ Treatment } & \multicolumn{6}{|c|}{ Means of variables ${ }^{*}$} \\
\hline & & $\begin{array}{l}\text { Germination } \\
(\%)\end{array}$ & $\begin{array}{l}\text { Shoot length } \\
\text { (cm) }\end{array}$ & $\begin{array}{l}\text { Root length } \\
\text { (cm) }\end{array}$ & $\begin{array}{l}\text { Dry weight } \\
\text { (g) }\end{array}$ & $\begin{array}{l}\text { Seedling } \\
\text { growth rate }\end{array}$ & $\begin{array}{l}\text { Seedling vigour } \\
\text { index }\end{array}$ \\
\hline \multirow[t]{16}{*}{ Supa } & Control & & & & & & \\
\hline & SDW & $96.00 \mathrm{a}$ & $10.50 \mathrm{ab}$ & $15.44 \mathrm{a}$ & $0.13 \mathrm{a}$ & $0.006 \mathrm{a}$ & $2369 \mathrm{ab}$ \\
\hline & Apron $\operatorname{Star}^{\circledR} 42$ WS & $95.00 \mathrm{a}$ & $9.55 \mathrm{~b}$ & $14.57 \mathrm{a}$ & $0.10 \mathrm{~b}$ & $0.004 \mathrm{~b}$ & $2100 \mathrm{~b}$ \\
\hline & Extracts source & & & & & & \\
\hline & Zingiber officinalis & 97.00 a & $10.44 \mathrm{ab}$ & 15.38 a & $0.12 \mathrm{a}$ & 0.006 a & $2345 \mathrm{ab}$ \\
\hline & Azadirachta indica & $97.00 \mathrm{a}$ & $10.47 \mathrm{ab}$ & $16.05 \mathrm{a}$ & $0.13 \mathrm{a}$ & 0.006 a & $2380 \mathrm{ab}$ \\
\hline & Coffee arabica & $96.00 \mathrm{a}$ & $10.38 \mathrm{ab}$ & $15.47 \mathrm{a}$ & $0.12 \mathrm{a}$ & $0.005 \mathrm{ab}$ & $2362 \mathrm{ab}$ \\
\hline & Camellia sinensis & 97.50 a & 11.67 a & 15.06 a & $0.14 \mathrm{a}$ & 0.006 a & 2435 a \\
\hline & Nicotiana tabacum & $97.00 \mathrm{a}$ & $10.09 \mathrm{~b}$ & 16.18 a & $0.13 \mathrm{a}$ & $0.005 \mathrm{ab}$ & $2424 \mathrm{ab}$ \\
\hline & Aloe vera & 96.00 a & 11.67 a & $15.06 \mathrm{a}$ & $0.14 \mathrm{a}$ & 0.006 a & $2375 \mathrm{ab}$ \\
\hline & Datura stramonium & 96.50 a & $10.62 \mathrm{ab}$ & $15.32 \mathrm{a}$ & $0.12 \mathrm{a}$ & $0.006 \mathrm{ab}$ & $2351 \mathrm{ab}$ \\
\hline & Allium sativum & $96.00 \mathrm{a}$ & $10.65 \mathrm{ab}$ & 15.19 a & $0.13 \mathrm{a}$ & $0.0060 \mathrm{ab}$ & $2376 \mathrm{ab}$ \\
\hline & Mean & 96.40 & 10.60 & 15.37 & 0.12 & 0.006 & 2352 \\
\hline & $\mathrm{LSD}_{0.05}$ & 2.21 & 1.15 & 1.83 & 0.01 & 0.001 & 280.0 \\
\hline & $\mathrm{F}$ test & ns & ${ }^{*}$ & ns & $* * *$ & ns & ns \\
\hline & CV (\%) & 1.6 & 7.5 & 8.2 & 8.2 & 17.9 & 8.2 \\
\hline \multirow[t]{16}{*}{ Saro-5 } & Control & & & & & & \\
\hline & SDW & 95.50 a & $11.46 \mathrm{~b}$ & $14.02 \mathrm{a}$ & $0.13 \mathrm{ab}$ & $0.006 \mathrm{a}$ & 2399 a \\
\hline & Apron Star ${ }^{\circledast} 42$ WS & $91.50 \mathrm{~b}$ & $9.76 \mathrm{c}$ & $13.48 \mathrm{a}$ & $0.10 \mathrm{~b}$ & $0.005 \mathrm{a}$ & 2011 a \\
\hline & Extracts source & & & & & & \\
\hline & Zingiber officinalis & 94.50 a & 13.32 a & 15.38 a & $0.12 \mathrm{ab}$ & 0.006 a & 2474 a \\
\hline & Azadirachta indica & $95.50 \mathrm{a}$ & $12.79 \mathrm{ab}$ & $15.53 \mathrm{a}$ & $0.11 \mathrm{ab}$ & $0.005 \mathrm{a}$ & 2448 a \\
\hline & Coffee arabica & 95.50 a & $12.39 \mathrm{ab}$ & $14.00 \mathrm{a}$ & $0.14 \mathrm{a}$ & 0.006 a & 2480 a \\
\hline & Camellia sinensis & $95.00 \mathrm{a}$ & $11.80 \mathrm{~b}$ & $14.64 \mathrm{a}$ & $0.12 \mathrm{ab}$ & $0.006 \mathrm{a}$ & 2430 a \\
\hline & Nicotiana tabacum & $95.00 \mathrm{a}$ & $12.20 \mathrm{ab}$ & $14.00 \mathrm{a}$ & $0.12 \mathrm{ab}$ & $0.005 \mathrm{a}$ & 2383 a \\
\hline & Aloe vera & $94.50 \mathrm{a}$ & $11.97 \mathrm{~b}$ & $14.76 \mathrm{a}$ & 0.13 a & $0.006 \mathrm{a}$ & 2436 a \\
\hline & Datura stramonium & 96.00 a & $11.99 \mathrm{~b}$ & 15.36 a & $0.13 \mathrm{a}$ & 0.006 a & 2500 a \\
\hline & Allium sativum & $95.00 \mathrm{a}$ & $11.59 \mathrm{~b}$ & $14.84 \mathrm{a}$ & $0.12 \mathrm{ab}$ & $0.006 \mathrm{a}$ & 2369 a \\
\hline & Mean & 94.80 & 11.93 & 14.60 & 0.12 & 0.006 & 2393 \\
\hline & $\mathrm{LSD}_{0.05}$ & 2.56 & 1.19 & 2.15 & 0.02 & 0.001 & 264.6 \\
\hline & F test & ns & ${ }^{* * *}$ & ns & ns & ns & ns \\
\hline & CV\% & 1.9 & 6.9 & 10.2 & 12.0 & 10.9 & 7.7 \\
\hline \multirow[t]{16}{*}{ Mwangaza } & Control & & & & & & \\
\hline & SDW & 95.50 a & $11.87 \mathrm{ab}$ & $15.24 \mathrm{a}$ & $0.11 \mathrm{a}$ & $0.005 \mathrm{a}$ & 2548 a \\
\hline & Apron Star ${ }^{\circledR} 42$ WS & 94.50 a & $10.71 \mathrm{~b}$ & $12.82 \mathrm{~b}$ & $0.09 \mathrm{a}$ & $0.005 \mathrm{a}$ & $2200 \mathrm{~b}$ \\
\hline & Extracts source & & & & & & \\
\hline & Zingiber officinalis & 95.50 a & $11.68 \mathrm{~b}$ & $14.94 \mathrm{a}$ & $0.11 \mathrm{a}$ & $0.005 \mathrm{a}$ & $2472 \mathrm{a}$ \\
\hline & Azadirachta indica & 95.00 a & 12.75 a & $15.02 \mathrm{a}$ & $0.10 \mathrm{a}$ & $0.005 \mathrm{a}$ & $2434 \mathrm{ab}$ \\
\hline & Coffee arabica & $95.00 \mathrm{a}$ & $11.99 a b$ & $14.33 \mathrm{a}$ & $0.11 \mathrm{a}$ & $0.005 \mathrm{a}$ & $2418 \mathrm{ab}$ \\
\hline & Camellia sinensis & $95.00 \mathrm{a}$ & $11.74 \mathrm{ab}$ & $14.70 \mathrm{a}$ & $0.10 \mathrm{a}$ & $0.005 \mathrm{a}$ & 2499 a \\
\hline & Nicotiana tabacum & $95.00 \mathrm{a}$ & $11.63 \mathrm{~b}$ & $14.53 \mathrm{a}$ & $0.12 \mathrm{a}$ & $0.005 \mathrm{a}$ & $2402 \mathrm{ab}$ \\
\hline & Aloe vera & 95.50 a & $11.74 \mathrm{ab}$ & $14.95 \mathrm{a}$ & $0.10 \mathrm{a}$ & $0.005 \mathrm{a}$ & 2462 a \\
\hline & Datura stramonium & $95.50 \mathrm{a}$ & $11.85 \mathrm{ab}$ & $15.48 \mathrm{a}$ & $0.11 \mathrm{a}$ & $0.005 \mathrm{a}$ & $2429 \mathrm{ab}$ \\
\hline & Allium sativum & 95.50 a & $11.83 \mathrm{ab}$ & $14.69 \mathrm{a}$ & $0.11 \mathrm{a}$ & $0.005 \mathrm{a}$ & $2441 \mathrm{ab}$ \\
\hline & Mean & 95.20 & 11.78 & 14.67 & 0.10 & 0.005 & 2431 \\
\hline & $\mathrm{LSD}_{0.05}$ & 2.72 & 0.92 & 1.38 & 0.02 & 0.001 & 221.9 \\
\hline & $\mathrm{F}$ test & ns & ${ }^{*}$ & $\mathrm{~ns}$ & ns & ns & ns \\
\hline & CV\% & 2.0 & 5.4 & 6.5 & 14.3 & 12.3 & 6.3 \\
\hline
\end{tabular}

*Values are means of four replicates. Numbers followed by the same letter in a column are not significantly different at $\mathrm{P}=0.05$, using Duncan's Multiple Range Test. ${ }^{* * *}=$ highly significantly different $(\mathrm{P}<0.001)$; $^{*}=$ significantly different $(\mathrm{P}<0.05)$; ns $=$ not significantly different. 
the plant extracts used were not phytotoxic to rice seedlings. These results are in agreement with those reported by Zida et al. [23], who showed that Apron $\operatorname{Star}^{\circledR} 42$ WS reduced seedling emergence, plant vigour and grain yield of pearl millet seeds. Seed treatments using ethanol extract and essential oil from Callistemon, Citrinus and Ocinum gratissimum improved the field parameters such as emergence and yield of tested rice varieties against Bipolaris oryzae [37]. The current findings suggest that leaf extracts from A. indica, A. vera, A. sativum, D. stramonium, C. sinensis, $N$. tabacum, Z. officinalis and processed C. arabica, can be used as seed treatments for the control of $P$. grisea in rice seeds and for improving rice seedling growth. These plant extracts are safe and eco-friendly on rice compared to synthetic chemicals such as Apron $\operatorname{Star}^{\circledR} 42$ WS. More studies are therefore, needed to confirm current findings and to determine the most effective formulation against $P$. grisea.

Identification and characterization of the active compounds from currently tested plant extracts and their role in rice blast disease control is also needed. Research on the range of activity of plant extracts for control of other rice pathogens is recommended.

\section{Conclusion}

This study has revealed that plant extracts from processed coffee (C. arabica) at concentrations of $10 \%$ and $25 \%$ (w/v) had the highest inhibitory effect (81.12\% and $89.40 \%$, respectively) against $P$. grisea - the causal agent of rice blast disease. These results generally indicated that, the plant extracts used were not phytotoxic to rice seedlings. More studies are therefore needed to confirm the current findings and to determine the most effective formulation against $P$. grisea.

\section{Acknowledgements}

The authors wish to thank the Alliance for Green Revolution in Africa (AGRA) for financial support for this work.

\section{References}

[1] Ghazanfar, M.U., Habib, A. and Sahi, S.T. (2009) Screening of Rice Germplasm against Pyricularia oryzae, the Cause of Rice Blast Disease. Pakistan Journal Phytopathology, 21, 41-44.

[2] Sukanya, S.L., Yamini, D. and Fathima, S.K. (2011) Eco-Friendly Management of Pyricularia oryzae, the Causal Agent of Blast of Paddy. Journal of Current Botany, 2, 46-49.

[3] TeBeest, D.O., Guerber, C. and Ditmore, M. (2007) Rice Blast. Journal of Plant Disease, 10,109-113.

[4] International Rice Research Institute (IRRI) (2010) Magnaporthegrisea: Rice Blast. http://www.metapathogen.com.visited

[5] Luzi-Kihupi, A., Zakayo, J.A., Tusekelege, H., Mkuya, M., Kibanda, N.J.M., Khatib, K.J. and Maerere, A. (2009) Mutation Breeding for Rice Improvement in Tanzania. Food and Agriculture Organization, United Nations, Rome.

[6] Kato, K. (2007) Development of a Major Rice Cultivation Area in the Kilombero Valley, Tanzania. African Study Monographs, 36, 3-18.

[7] Mossini, S.A.G., Oliveira, K.P. and Kemmelmeier, C. (2004) Inhibition of Patulin Production by Penicilliumexpansum Cultured with Neem (Azadirachtaindica) Leaf Extracts. Journal of Basic Microbiology, 44, 106-113. http://dx.doi.org/10.1002/jobm.200310332

[8] Mwilene, F.E., Oikeh, S.O., Agunibiade, T.A., Oladimeji, O., Ajayi, O., Sie, M., Gregorio, G.B., Togola, A. and Toure, A.D. (2008) Growing Lowland Rice. In: Production Handbook, Africa Rice Center (WARDA), Bouaké.

[9] International Rice Research Notes (IRRN) (1993) Treating Rice Seeds with Fungicides and Antagonists to Control Seed-Borne Diseases.

[10] Mbodi, Y., Gaye, S. and Diaw, S. (1986) The Role of Tricyclazole in Rice Protection against Blast and Cultivar Improvement. Journal of Parasitica, 43, 187-198.

[11] Khan, Z.S. and Nasreen, S. (2010) Phytochemical Analysis, Antifungal Activity and Mode of Action of Methanol Extracts from Plants against Pathogens. Journal of Agricultural Technology, 6, 793-805.

[12] Peter, A.C.O. (2005) Non-Pesticide Methods for Controlling Diseases and Insect Pests. Integrated Pest Management Expert and Food and Agriculture Organization, Bangkok.

[13] Amadioha, A.C. (2000) Controlling Rice Blast in Vitro and in Vivo with Extracts of Azadirachta indica. Journal of Crop Protection, 19, 287-290. http://dx.doi.org/10.1016/S0261-2194(99)00080-0 
[14] Jabeen, R. (2006) Evaluation of Botanicals against Xanthomonas oryzae pv. oryzae Using Bacterial Leaf Blight Disease of Rice and Characterization of Bioactive Compounds. MSc. Dissertation, Quaid-i-Azam University, Islamabad.

[15] Lalitha, V., Raveesha, K.A. and Kiran, B. (2010) Antimicrobial Activity of Solanum torvum Swart. against Important Seed Borne Pathogens of Paddy. Iranica Journal of Energy \& Environment, 1, 160-164.

[16] Enikuomehin, O.A. (2005) Cercospora Leaf Spot Disease Management in Sesame (Sesamum indicum L.) with Plant Extracts. Journal of Tropical Agriculture, 43, 19-23.

[17] Gurjar, M.S., Ali, S., Akhtar, M. and Singh, K.S. (2012) Efficacy of Plant Extracts in Plant Disease Management. Journal of Agricultural Sciences, 3, 425-433. http://dx.doi.org/10.4236/as.2012.33050

[18] Mathur, S.B. and Kongsdal, O. (2004) Common Laboratory Seed Healthy Testing Methods for Detecting Fungi. 2nd Edition, International Seed Testing Association (ISTA), Bassersdorf.

[19] Harlapur, S.I., Kulkarni, M.S., Wali, M.C. and Kulkarni, S. (2007) Evaluation of Plant Extracts, Bio-Agents and Fungicides against Exserohilum turcicum (Pass.) Leonard and Suggs. Causing Turcicum Leaf Blight of Maize. Journal of Agricultural Sciences, 20, 541-544.

[20] Akinbode, O.A. and Ikotun, T. (2008) Evaluation of Some Bio-Agents and Botanicals in in Vitro Control of Colletotrichuwm destructivum. African Journal of Biotechnology, 7, 868-872.

[21] Hasan, M.M., Chowdhury, S.P., Alam, S., Hossain B. and Alam, M.S. (2005) Antifungal Effects of Plant Extracts on Seed-Borne Fungi of Wheat Seed Regarding Seed Germination, Seedling Healthy and Vigor Index. Journal of Biological Sciences, 8, 1284-1289.

[22] Nduagu, C., Ekefan, E.J. and Nwankiti, A.O. (2008) Effect of Some Crude Plant Extracts on Growth of Colletotrichum capsici (Synd) Butler and Bisby, Causal Agent of Pepper Anthracnose. Journal of Applied Biosciences, 6, 184-190.

[23] Zida, E.P., Sereme, P., Leth, V. and Sankara, P. (2008) Effect of Acacia gourmaensis A. Chev and Eclipta alba (L.) Hassk. on Seed Health, Seedling Vigour and Grain Yield of Sorghum and Pearl Millet. Asian Journal of Plant Pathology, 2, 40-47. http://dx.doi.org/10.3923/ajppaj.2008.40.47

[24] Mamiro, D.P. and Royse, D.J. (2004) Laboratory Efficacy of Selected Fungicides and Rhododendron catawbiense Leaf Extracts on the Growth of Vericillium fungicola. Acta Edulis Fungi, 12, 390-396.

[25] Kamalakannan, A. and Shanmugam, V. (2005) Controlling Downy Mildew of Maize Caused by Peronosclerospora sorghi by Prosopis chilensis, Azadirachta indica and Foliar Sprays of a Talc-Based Formulation of a Pseudomonas fluorescens. Plant Pathology, 18, 115-118.

[26] Ogbebor, N. and Adekunle, A.T. (2005) Inhibition of Conidial Germination and Mycelial Growth of Corynespora cassiicola (Berk and Curt) of Rubber (Hevea Brasiliensis Muell. Arg.) Using Extracts of Some Plants. African Journal of Biotechnology, 4, 996-1000.

[27] Namai, T. and Ehara, Y. (1986) Studies on Variation in Virulence of Rice Blast Fungus, Pyricularia oryzae Cavara. Journal of Agricultural Research, 36, 3-4.

[28] Chala, A., Brurberg, M.B. and Tronsmo, A.M. (2010) Incidence and Severity of Sorghum Anthracnose in Ethiopia. Plant Pathology, 9, 23-30. http://dx.doi.org/10.3923/ppj.2010.23.30

[29] International Seed Testing Association (ISTA) (2008) International Rules for Seed Testing. Bassersdorf.

[30] Mbega, E.R., Mortensen, C.N., Mabagala, R.B. and Wulff, E.G. (2012) The Effect of Plant Extracts as Seed Treatments to Control Bacterial Leaf Spot of Tomato in Tanzania. Journal of General Plant Pathology, 78, 277-286. http://dx.doi.org/10.1007/s10327-012-0380-z

[31] Chhetri, S. (2009) Identification of Accelerated Aging Conditions for Seed Vigor Test in Rice (Oryza sativa L.). Ph.D. Thesis, Thawatchai Teekachunhatean, Nakhon Ratchasima.

[32] Kamalakannan, A., Shanmugam, V., Surendran, M. and Srinivasan, R. (2001) Antifungal Properties of Plant Extracts against Pyricularia grisea, the Rice Blast Pathogen. Indian Journal of Phytopathology, 54, 490-492.

[33] Taiga, A. and Friday, E. (2009) Variations in Phytochemical Properties of Selected Fungicidal Aqueous Extracts of Some Plant Leaves in Kogi State, Nigeria. American-Eurasian Journal of Sustainable Agriculture, 3, 407-409.

[34] Hajano, J.U., Lodhi, A.M., Pathan, M.A., Khanzada, M.A. and Shah, G.S. (2012) In Vitro Evaluation of Fungicides, Plant Extracts and Bio-Control Agents against Rice Blast Pathogen Magnaporthe oryzae Couch. Pakistan Journal of Botanical, 44, 1775-1778.

[35] Yeni, I.J. (2011) Evaluation of Antifungal Effects of Extracts of Allium sativum and Nicotiana tabacum against Soft Rot of Yam (Dioscorea alata). Journal of Agricultural Research, 3, 1-5.

[36] Obongoya, B.O., Wagai, S.O. and Odhiambo, G. (2009) Fungitoxic Properties of Four Crude Plant Extracts on Fusarium oxysporum Schl. F. sp. Phaseoli. African Journal of Food Agriculture Nutrition and Development, 9, 1652-1666. http://dx.doi.org/10.4314/ajfand.v9i8.48404 
[37] Nguefack, J., Torp, J., Leth, V., Dongmo, J.B., Fotio, D. and Amvam Zollo, P.H. (2007) Effects of Plant Extracts and Chemical Fungicide in Controlling a Rice Seed-Borne Fungus under Laboratory and in Irrigated Cropping System in Ndop-Cameroon. African Journal of Crop Science, 8, 791-796. 